RESENHA

\title{
O século XXI no Brasil e no mundo*
}

ROGÉRIO DE SOUZA FARIAS**

Theodore Hook, escritor inglês, afirmava que a melhor forma de predizer o futuro é inventando-o. Esse mote singulariza muito bem o empreendimento de desbravadores, inventores e vanguardistas da arte, pois a engenhosidade humana parece dispor de irrestrito estoque de surpresas que transformam o espaço e a consciência que temos de nós mesmos. É com artifício semelhante que gerações de pesquisadores perscrutam uma grande "invenção" coletiva, que é a realidade social que nos cerca.

Para examiná-la, criam-se métodos, derrubam-se axiomas e debatem-se idéias - um processo que redunda na grade de conhecimento que ajuda a tornar compreensível os complexos processos que enfrentamos. Nos últimos anos, contudo, esses exercícios demandam cada vez mais desvelo e mobilização por parte dos corifeus da academia, pois a realidade parece constituir um agregado difícil de decompor, de dar inteligibilidade e de explicar.

Não há domínio mais explícito nesse sentido que a política internacional, âmbito no qual imperava, até décadas atrás, uma lógica se não longeva, pelo menos familiar ao longínquo passado. As agremiações coletivas, reunidas nas linhas de unidades semelhantes ao Estado moderno, moviam dentro do jogo do poder e da cooperação clássico, na busca pelo poder, afluência e bem-estar de seus indivíduos e unidades constituintes.

Essas características, porquanto ainda presentes na hodierna realidade, empalidecem frente ao revoluto caos de atores que participam das mais diversas interaçôes nas esferas contemporâneas da agenda internacional - do comércio internacional ao meio ambiente; dos direitos humanos à proliferação nuclear. É com objetivo de analisar diversas dessas categorias e atores que a Edusc brinda a comunidade de Relações Internacionais com a coletânea organizada por Maria Izabel Valladão de Carvalho e Maria Helena de Castro Santos.

O livro originou-se dos trabalhos apresentados no $2^{\circ}$ Seminário de Política Internacional e Comparada, realizado na Universidade de Brasília com apoio do programa San Tiago Dantas/Capes-UnB, em março de 2005. No entanto,

${ }^{*}$ Resenha de CARVALHO, Maria Izabel Valladão de e SANTOS, Maria Helena de Castro (orgs.). O século XXI no Brasil e no mundo. Bauru: Edusc, 2006. ISBN: 85-7460-320-1

** Mestrando em Relaçōes Internacionais pela Universidade de Brasília - UnB (rofarias@gmail.com). 
ao contrário de diversas publicações decorrentes de encontros acadêmicos, o livro apresenta-se como uma construção harmônica, mesmo contendo várias facetas - o liame que conecta os capítulos é a tese de que a visão realista clássica das Relações Internacionais não é mais adequada para a compreensão do mundo contemporâneo.

Há uma divisão dos capítulos em três partes, que são explicativos tanto do ponto de vista temático como teórico. A primeira trata o tema da "segurança internacional e regional”, aspecto de proeminência nas agendas de pesquisa da academia, principalmente após os atentados de 11 de Setembro - ocupa cinco dos nove capítulos do livro. A segunda lida com a interação entre processos de negociação domésticos e internacionais na área de comércio internacional - na esteira dos trabalhos de Robert Putnam, Christopher Meyerson e Christina Davis -, com o instigante texto de Maria Izabel Valladão de Carvalho. Por fim, a terceira e última parte do livro traz interessantes contribuições no macrotema de "transformaçôes globais, atores não governamentais e subnacionais".

Percebe-se, não obstante esse esforço de divisão, que há um claro curso subterrâneo entre os três segmentos do livro - as fronteiras que compartimentam a obra são porosas, da mesma forma que os autores enxergam as fronteiras que dividem os Estados no sistema internacional. $\mathrm{O}$ tema dos indivíduos e grupos em suas interações nacionais e transnacionais, dessa maneira, pode ser encontrado no polêmico e interessante trabalho de Héctor Ricardo Leis, sobre os desafios da sustentação estatal frente ao desafio das forças civis, notadamente as de cunho revolucionário e anti-estatal; no tratamento dos grupos de interesse e instituições domésticas na área de comércio internacional, como é o caso do trabalho de Maria Izabel Valladão; e nos trabalhos de Ana Flávia Barros-Platiau e Cristina Inoue, respectivamente sobre o tratamento teórico da influência de atores não-estatais na política internacional ambiental e sobre a rede de interações de atores e comunidades epistêmicas no caso do projeto de criação da unidade de conservação de Mamirauá, no Pará.

A pluralidade de temas é complementada pela hábil capacidade de os autores usarem uma ampla gama de modernas e arrojadas teorias, lentes que proporcionam uma organização interessante dos desafios e categorias do nosso conturbado mundo. Casos há em que é a teoria o principal objeto de análise, como é o caso do capítulo de Lawrence Sáez, que examina o alcance explicativo das teorias que relacionam interdependência econômica e cooperação política. Um outro tema de especial relevância, mas que ainda tem uma discussão incipiente no Brasil, é o tratamento da diplomacia federativa, analisado no penúltimo capítulo por Tullo Vigevani. Aqui há uma questão interessante, pois os marcos jurídico-institucionais estaduais parecem, criar situaçóes inovadoras que não representam estritamente os marcos legais, ao mesmo tempo em que há a necessidade de reconstruí-los para possibilitar uma maior incorporação da diplomacia federativa à ação externa brasileira. 
Por fim, dois capítulos merecem especial menção, pelos acontecimentos do corrente ano. O primeiro é o exame bem informado de Peter Wallenstein sobre a ONU. O autor aborda a evolução dos marcos institucionais e normativos da organização, relevando os desafios dos conflitos armados após o fim da Guerra Fria para a instituição. Apesar do tom otimista de sua avaliação, principalmente sobre o Conselho de Segurança, é um texto interessante para se avaliar o corrente processo de discussão de reforma, que morosamente boceja os corredores e plenários de sua sede. O segundo é o de Mônica Hirst, uma excelente discussão do tema da crise do Estado na América do Sul. O trabalho conta com uma excelente revisão da literatura sobre o tema, notadamente no contexto da segurança internacional pós 11 de Setembro. Mais interessante, contudo, é a forma pela qual os casos do Haiti, Bolívia e Paraguai são avaliados no contexto específico da região. A autora, em percuciente análise, traz soluções inovadoras que tentam contornar os perigos que a securitização da agenda política, promovida pelos americanos, para construir uma estabilidade regional amparada por um papel mais ativo do Brasil na área.

O livro é muito bem editado, com a exceção das referências bibliográficas dos capítulos 3 e 5, que não estão dispostas ao final dos respectivos textos, como é o padrão dos demais. É uma publicação que merecerá um lugar especial nas prateleiras dos interessados na dinâmica da política internacional contemporânea, pois os autores não se conformam com o diletante exercício de análise; há, na maioria dos capítulos, uma inequívoca habilidade de desdobrar para o futuro um prognóstico ou proposta, uma "invenção informada", que, assim como a assertiva de Theodore Hook, aclara as lentes que imaginarão e construirão o futuro. 